\title{
Therapeutic effects of Laser and L-carnitine against amiodarone-induced pulmonary toxicity in adult male rats
}

\author{
Walaa AM El-Nahrawy ${ }^{1}$, Amr ME Zaher ${ }^{2}$ and Sara MR Ali ${ }^{1 *}$ \\ ${ }^{1}$ Zoology Department, Women's College, Ain Shams University, ${ }^{2}$ National Heart Institute and National Institute of Laser \\ Enhanced Science, Cairo, Egypt
}

${ }^{\star}$ For correspondence: Email: sara.m.refaat@gmail.com; Tel: +202-127-5504599

\begin{abstract}
Purpose: To compare the effects of laser and/or L-carnitine (LC) on amiodarone (AM)-induced lung toxicity in adult male rats.

Methods: Lung toxicity was induced in 50 healthy male albino rats (150-180 g) by AM for 8 weeks. The rats were divided into 4 groups (7 per group): AM recovery, LC, laser, and laser + LC. After a 4-week exposure to laser and/or LC, key antioxidant enzymes, nitric oxide (NO), angiotensin II, cyclooxygenase-II (COX-II) and lipoxygenase (LOX) as well as oxidative stress and inflammation parameters were determined.

Results: Administration of $L C$ and/or laser exposure led to significant increases in reduced glutathione (GSH), superoxide dismutase (SOD), catalase (CAT) and angiotensin II; and significant decreases in nitric oxide (NO) level and glutathione-S-transferase (GST) activity in the AM-treated rats when compared with the $A M$ recovery group $(p<0.05)$. The $L C$ and/or laser exposure also significantly inhibited COX II and LOX activities in the lungs, and brought about significant reduction in levels of $T N F-\alpha$ and lipid peroxidation (LPO), and significant increases in cytochrome levels $(p<0.05)$.

Conclusion: These results indicate that $A M$ induced pulmonary fibrosis in rats. However, $A M$ withdrawal and treatment by $L C$ and/or exposure to laser exerted mitigating effects against the $A M$ induced fibrosis.
\end{abstract}

Keywords: Amiodarone, Lung toxicity, Laser; L-carnitine

Tropical Journal of Pharmaceutical Research is indexed by Science Citation Index (SciSearch), Scopus, International Pharmaceutical Abstract, Chemical Abstracts, Embase, Index Copernicus, EBSCO, African Index Medicus, JournalSeek, Journal Citation Reports/Science Edition, Directory of Open Access Journals (DOAJ), African Journal Online, Bioline International, Open-J-Gate and Pharmacy Abstracts

\section{INTRODUCTION}

The lung is the primary organ of respiration in humans and many lower animals. Lung tissue may be affected by many diseases such as pneumonia, lung cancer and lung fibrosis, due to exposure to harmful substances. Pulmonary fibrosis is a lung disease characterized by scarring of lung tissue, leading to breathing problems and other symptoms. The fibrotic scar and excess accumulation of fibrous connective tissue thicken the walls of the lung tissue and reduce oxygen supply to the blood, leading to shortness of breath [1].

Pulmonary toxicity is considered a lifethreatening complication of amiodarone usage. In medicine, most of pulmonary toxicity diseases are caused by side effects of drugs. Druginduced pulmonary toxicity can lead to fibrosis [2].

Amiodarone (AM) is a derivative of iodine benzofuran $\mathrm{HCl}$ (marketed as Pacerone or Cordarone). It is considered the strongest and most effective anti-arrhythmic drug because it 
surpasses other agents in its ability to prevent and treat ventricular and supraventricular dysrhythmias. However, the use of AM is often limited by adverse reactions involving many different organ systems [3]The toxicity of AM which manifests in pneumonia can be seen as adult respiratory distress syndrome (ARDS); it has a high rate of mortality (about $50 \%$ of patients) [4], and can lead to severe pulmonary fibrosis [5].

The carnitine system consists of L-carnitine (C7H15NO3), acetyl-carnitine (C9H17NO) and the cellular proteins which are required for metabolism and transport. L-carnitine consists of amino acids naturally produced in humans and lower animals. It plays a role as a carrier for translocation of long-chain fatty acids from the cytosol into the mitochondria for $\beta$-oxidation [6].

The use of low levels of visible light to reduce inflammation-related pain, promote healing of deep wounds in tissues and nerves, and prevent tissues from damage have been documented These applications are based on the fact that that low level (soft-cold) lasers do not have thermal effects on tissues: lasers that stimulate biological function have an output below 10 milliwatts [7]. The effect of laser on tissue depends on the absorption of monochromatic visible rays by the components of the cellular respiratory chain of mitochondria. Evidence shows that treatment by laser light (low-level) induces the mitochondria to increase ATP production [8].

The present study focused on the potential therapeutic effects of L-carnitine and laser, either singly or synergistically, on lung toxicity induced by AM.

\section{EXPERIMENTAL}

\section{Materials}

Amiodarone (AM, empirical formula $\mathrm{C}_{25} \mathrm{H}_{29} \mathrm{I}_{2}$ $\mathrm{NO}_{3}$ ) and L-carnitine (3-hyroxy, 4-trimethylamino butyric acid) were obtained from Sigma Chemical Company (USA). Therapeutic low-intensity red laser module with more patterns projector was purchased from Shenzhen Light Technology Co. Ltd (China).

\section{Experimental animals}

Healthy 50 adult male albino rats $(150-180 \mathrm{~g}$, aged 6 - 7 weeks were used in this study. They were obtained from Medical and Bilharzia Research Center, Faculty of Medicine, Ain Shams University, Egypt.
The animals were housed in separate cages at room temperature $\left(22 \pm 4^{\circ} \mathrm{C}\right)$, with free access to water and feed. Blood parasitological tests and clinical examination were performed to ensure the animals were healthy. Amiodarone and Lcarnitine were administered at doses of 30 and $100 \mathrm{mg} / \mathrm{kg}$ body weight, for 8 weeks and 30 days, respectively by oro-gastric tube $[9,10]$.

The study procedures were performed in line with the ethical guide for the care and use of laboratory animals of theU.S. National Research Council of the National Academics [11].

The experimental procedures were approved by thelnstitutional Animal Care and Use Committee (IACUC), Faculty of Science, Menofia University, Egypt (approval no. MNSH174).

\section{Animal groups}

The rats were randomly assigned to five groups, each containing 7 animals: (i) control group: rats received $0.5 \mathrm{ml}$ distilled water through oro-gastric tube; (ii) AM recovery group: rats in this group did not receive any treatment for 30 days after exposure to AM (30 mg / kg/ BWT) for 60 days [10]; (iii) AM+LC group: after exposure to AM (30 $\mathrm{mg} / \mathrm{kg}$ BWT) for 60 days, the rats received LC (100 mg/kg BWT) for 30 days [9], and (iv) AM + laser group: after AM exposure, the rats were exposed to laser [12] and (v) LC + laser: after AM treatment, the rats exposed to laser and received $L$-carnitine for 30 days.

\section{Exposure of animals to laser light}

The rats were anesthetized with ketamine $(80$ $\mathrm{mg} / \mathrm{kg}$ ) and xylazine (10 mg/kg/ BWT) [12]. Before exposure to laser light, hair was removed from $4 \mathrm{~cm}^{2}$ of abdominal area of each rat. Then, $1 \mathrm{~cm}^{2}$ of the lung-facing area was exposed to laser light $(650 \mathrm{~nm})$ for 2 minutes. On the 30th day of exposure, the rats were sacrificed then serum and lung tissue samples were collected for biochemical and histological assays.

\section{Comet assay}

The comet assay was done under alkaline conditions, including the unwinding of DNA to detect combination of DNA (single, double) strand breaks and alkali-labile sites in the DNA [3].

\section{Statistical analysis}

Data on lung parameters were expressed with mean \pm standard deviation. Statistical analysis was performed using ANOVA to analyze data in 
SPBS version 10. Values of $p<005$ were taken as statistically significant [13].

\section{RESULTS}

\section{Antioxidant levels}

Treatment of the rats with $\mathrm{AM}$ induced oxidative stress as demonstrated by significant decreases in GSH, SOD, CAT and Angiotensin II, which were accompanied by significant elevations in $\mathrm{NO}$ and GST contents when compared with control group ( $p<0.05$; Table 1). Oral administration of $L C$ and/or exposure of the AMtreated rats to laser led to significant elevations in GSH and angiotensin II levels, and in the activities of SOD and CAT, with concomitant significant decreases in NO and GST contents, relative to AM-treated rats $(p<0.05)$.

\section{Lung COX II and LOX activities}

The administration of $A M$ resulted in significant elevation in COX II and LOX activities in lung tissue when compared with the control group ( $p$ $<0.05$; Table 2). However, the activities of these two enzymes were significantly decreased in the AM-treated rats by LC and/ or laser exposure, relative to AM-treated rats $(p<0.05$; Table 2$)$.

\section{Oxidative stress and inflammation status}

The results also showed that $A M$ induced significant increases in serum TNF- $\alpha$ and LPO product when compared with control group $(p<$ 0.05; Table 2). However, LC and/or laser exposure led to significant reductions in TNF- $\alpha$ and in the degree of lipid peroxidation in AMtreated rats $(p<0.05$; Table 2$)$.

\section{Changes in cytochromes $\mathrm{P}_{450} \mathrm{~A}_{2}\left(\mathrm{CYP}_{1} \mathrm{~A}_{2}\right)$ and $\mathrm{P}^{450} \mathrm{E}_{2} \mathrm{E}_{1}\left(\mathrm{CYP}_{2} \mathrm{E}_{1}\right)$}

Table 2 also shows that serum levels of cytochromes CYP1A2 and CYP2E1 were significantly higher in the AM-treated rats when compared with the normal control $(p<0.05)$. On the other hand, treatment of the AM rats with LC and/or exposure to laser (Figure 1) significantly reduced the levels of CYP1A2, CYP2E1 relative to AM rats $(p<0.05)$.

Table 1: Effect of L-carnitine or/and laser on antioxidants (GSH, GST, SOD, and CAT), NO and angiotensin II levels in lung tissue of AM-treated rats (mean \pm SEM)

\begin{tabular}{rcccccc}
\hline Group \& treatment & $\begin{array}{c}\text { GSH } \\
\mathbf{~ g} \mathbf{m} \mathbf{m l}\end{array}$ & $\begin{array}{c}\text { GST } \\
\mathbf{u} / \mathbf{m l}\end{array}$ & $\begin{array}{c}\text { SOD } \\
\mathbf{u} / \mathbf{m l}\end{array}$ & $\begin{array}{c}\text { CAT } \\
\mathbf{m u} / \mathbf{m l}\end{array}$ & $\begin{array}{c}\text { NO } \\
\mathbf{n} / \mathbf{m o l}\end{array}$ & $\begin{array}{c}\text { Angiotensin II } \\
\mathbf{p g} / \mathbf{m l}\end{array}$ \\
\hline Control & 13.489 & 165.343 & 5.534 & 1.591 & 17.843 & 1.357 \\
& \pm 0.209 & \pm 0.399 & \pm 0.041 & \pm 0.018 & \pm 0.094 & \pm 0.008 \\
AM recovery & 5.550 & 515.490 & 2.339 & 0.693 & 66.557 & 0.462 \\
& \pm 0.029 & \pm 5.206 & \pm 0.040 & \pm 0.006 & \pm 0.554 & \pm 0.004 \\
AM+ L-carnitine & 10.364 & 301.570 & 4.071 & 1.330 & 29.408 & 1.106 \\
& \pm 0.134 & \pm 6.027 & \pm 0.050 & \pm 0.017 & \pm 0.760 & \pm 0.007 \\
AM + laser & 9.169 & 342.541 & 3.320 & 1.065 & 35.724 & 0.945 \\
AM + L-carnitine + & \pm 0.093 & \pm 5.543 & \pm 0.022 & \pm 0.023 & \pm 0.259 & \pm 0.012 \\
laser & 11.368 & 216.747 & 4.927 & 1.541 & 22.620 & 1.249 \\
\hline
\end{tabular}

Values are expressed as mean $\pm \operatorname{SEM}(n=10, p<0.05)$

Table 1: Effect of L-carnitine or/and Laser on the lung enzymes (COX, LOX), oxidative stress \&inflammatory status (TNF- $\alpha$, MDA) and cytochromes (CYP 1A2, CYP 2E1) contents in Amiodarone treated rats

\begin{tabular}{|c|c|c|c|c|c|c|}
\hline \multirow[b]{2}{*}{ Group \& treatment } & \multicolumn{2}{|c|}{ Lung enzyme } & \multicolumn{2}{|c|}{$\begin{array}{l}\text { Oxidative stress and } \\
\text { inflammatory status }\end{array}$} & \multicolumn{2}{|c|}{ Cytochrome } \\
\hline & $\begin{array}{c}C O X \\
n g / m I\end{array}$ & $\begin{array}{c}L O X \\
p g / m I\end{array}$ & $\begin{array}{l}T N F-\alpha \\
p g / m I\end{array}$ & $\begin{array}{l}L P O \\
\mu m\end{array}$ & $\begin{array}{c}C Y P_{1} A_{2} \\
p g / m l\end{array}$ & $\begin{array}{c}C Y P_{2} E \\
n g / m l\end{array}$ \\
\hline \multirow{2}{*}{ Control } & 4.607 & 12.600 & 1.526 & 6.517 & 4.650 & 13.754 \\
\hline & \pm 0.019 & \pm 0.023 & \pm 0.003 & \pm 0.012 & \pm 0.028 & \pm 0.078 \\
\hline \multirow{2}{*}{ AM Recovery } & 17.929 & 70.334 & 5.382 & 16.177 & 24.152 & 90.343 \\
\hline & \pm 0.463 & \pm 0.319 & \pm 0.053 & \pm 0.091 & \pm 0.317 & \pm 0.616 \\
\hline \multirow{2}{*}{ AM + L-carnitine } & 8.044 & 36.686 & 2.442 & 9.194 & 10.318 & 39.795 \\
\hline & \pm 0.198 & \pm 0.495 & \pm 0.068 & \pm 0.073 & \pm 0.114 & \pm 0.849 \\
\hline \multirow{2}{*}{$\mathrm{AM}+$ laser } & 10.433 & 48.772 & 3.227 & 11.333 & 13.944 & 55.717 \\
\hline & \pm 0.250 & \pm 0.579 & \pm 0.071 & \pm 0.044 & \pm 0.273 & \pm 0.596 \\
\hline \multirow{2}{*}{$\begin{array}{l}\mathrm{AM}+\mathrm{L} \text {-carnitine + } \\
\text { laser }\end{array}$} & 6.549 & 25.722 & 1.910 & 8.125 & 6.794 & 24.104 \\
\hline & \pm 0.134 & \pm 0.785 & \pm 0.030 & \pm 0.089 & 99 & \pm \\
\hline
\end{tabular}


Table 3: DNA damage in rats

\begin{tabular}{|c|c|c|c|c|}
\hline Group \& treatment & $\begin{array}{l}\text { Head/1000(mean } \\
\pm \text { SEM) }\end{array}$ & $\begin{array}{c}\text { DNA in } \\
\text { head (\%) }\end{array}$ & $\begin{array}{l}\text { Tail/1000(mean } \\
\pm \text { SEM) }\end{array}$ & $\begin{array}{c}\text { DNA in } \\
\text { tail }\end{array}$ \\
\hline Control & $\begin{array}{c}2.1 \\
\pm 0.20\end{array}$ & 33.8 & $\begin{array}{c}20.61 \\
\pm 2.1\end{array}$ & 62.2 \\
\hline AM recovery & $\begin{array}{r}5.9 \\
\pm 0.20\end{array}$ & 20.6 & $\begin{array}{c}30.51 \\
\pm 3.5\end{array}$ & 79.4 \\
\hline AM + L-Carnitine & $\begin{array}{c}4.5 \\
\pm 0.52\end{array}$ & 27.7 & $\begin{array}{c}28.51 \\
\pm 3.1\end{array}$ & 72.3 \\
\hline AM + Laser & $\begin{array}{c}4.01 \\
\pm 0.55\end{array}$ & 29.6 & $\begin{array}{l}26.1 \\
\pm 2.5\end{array}$ & 70.4 \\
\hline AM + L-carnitine + laser) & $\begin{array}{l}3.5 \\
\pm 0.61\end{array}$ & 31.9 & $\begin{array}{l}25.0 \\
\pm 5.1\end{array}$ & 66.2 \\
\hline
\end{tabular}

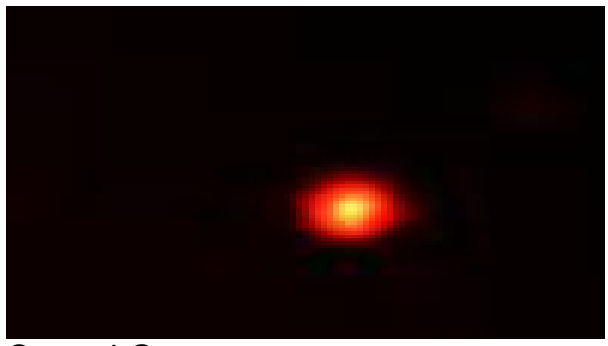

Control Group

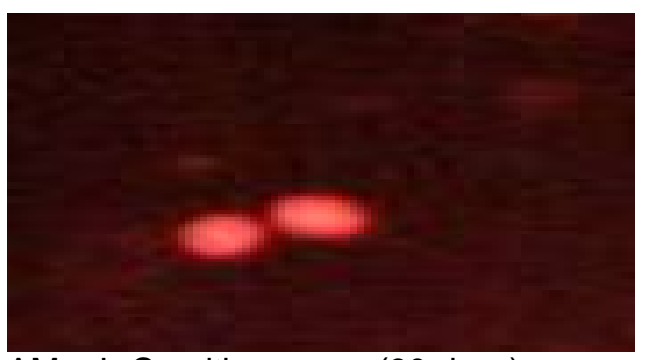

$\mathrm{AM}+\mathrm{L}-$ Carnitine group (30 days)

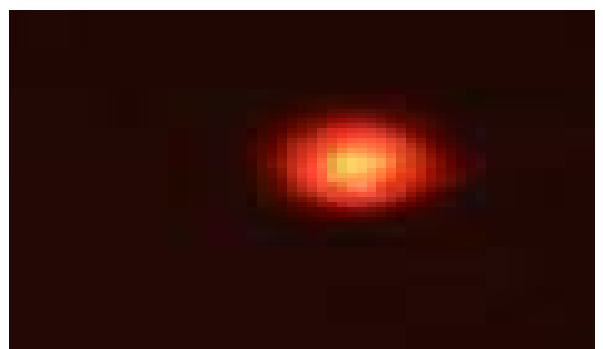

AM + L-carnitine + laser group (30 days)

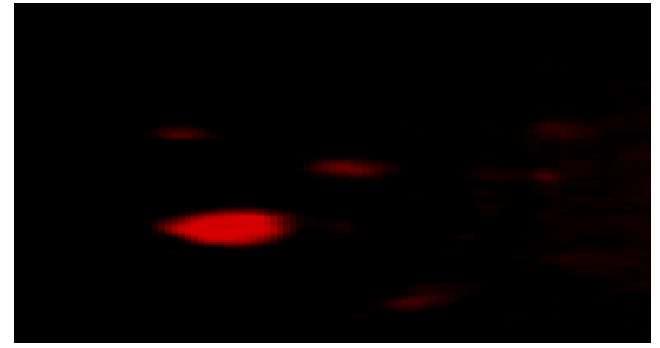

AM Recovery group (30 days)

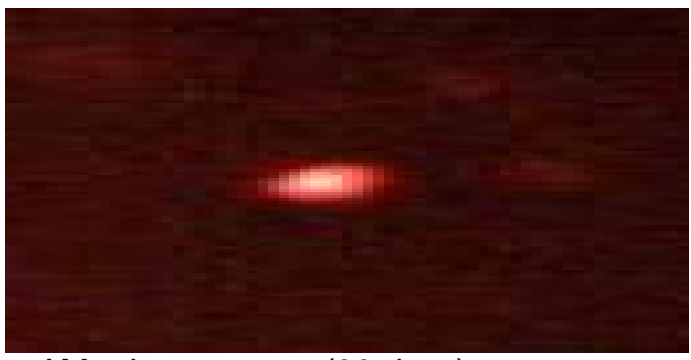

$\mathrm{AM}+$ Laser group (30 days)

Figure 1: Images of fragment and pattern of DNA migration by comet assay evaluated with a fluorescence microscopy of lung cells from the various groups.

\section{DISCUSSION}

Results from several studies have suggested that oxidant-antioxidant imbalance in the lower respiratory system plays a crucial role in pulmonary toxicity. Amiodarone administration results in interstitial alveolar inflammation [10]. In the present study, the administration of AM to rats induced marked elevations in NO and GST, and significant reductions in GSH, SOD, CAT and Angiotensin II when compared with control rats. These changes can be attributed to AM- induced pulmonary toxicity. Several mechanisms are involved in the accumulation of iodine-rich AM in pneumocytes [14]. The mechanisms involve direct toxic effect that disrupts cellular membranes through the activation of protein kinase $\mathrm{C}$, release of toxic reactive oxygen species (ROS), decreases in GSH, mitochondrial dysfunction, necrosis and ultimately apoptosis [15]. Amiodarone treatment has been reported to increase generation of free radicals, and production of mitochondrial hydrogen peroxide which could be metabolized to an aryl radical that 
may give rise to other ROS [16]. The strong oxidizing potential of ROS can lead to generation of advanced oxidation products and induce damage to cellular structures within the lungs. In addition, GSH plays an important role in a variety of detoxification processes. It has been reported that AM significantly reduced GSH levels in rat lung homogenate, suggesting its oxidationinduced role in lung toxicity [17].

The most important antioxidant enzymes in the lung are SOD and CAT. These antioxidant enzymes are the first lines of defense against oxidative damage [10]. Alveolar macrophages isolated from AM-treated rats released large amounts of TNF- $\alpha$ [18]. Pulmonary toxicity by AM is an immuno-mediated process involving an imbalance in T-helper cells and over-production of cytokines which are reported to significantly increase serum TNF- $\alpha$ [14].In addition, the oxidative capacity of ROS leads to generation of oxidation products and cellular damage within the lungs. Malondialdehyde (MDA) is an index of membrane LPO which damages pulmonary endothelium [17].

L-carnitine is a very effective antioxidant agent. In this study, LC significantly increased the levels of GSH, GST, SOD and NO. This is in agreement with a previous report on the antioxidant and free radical-scavenging properties of LC [19]. It has been suggested that LC is involved in ATP synthesis through its role in mobilization of mitochondrial fatty acids during $\beta$-oxidation. During ATP synthesis, massive oxygen consumption depletes oxygen and ROS levels. The anti-oxidant effect of LC is thought to be due its ability to increase the activity of antioxidant enzymes [20,21].

Laser therapy restores the balance between oxidants and antioxidants [22]. This is in agreement with the laser-induced significant increases in antioxidant parameters seen in the present study. The synergistic effects of laser and LC led to significant increases in GSH, SOD, CAT, GST and angiotensin II, as well as significant decreases in NO. Thus the laser restored the balance between oxidant and antioxidants [23].

Special laser light near the infrared region (NIR) is used to reduce pain, inflammation, and edema. It is also used to promote healing of deep tissue wounds, and to protect the nerves and prevent tissue damage. These uses of laser light are based on its properties and its ability to interact with living tissue to produce energy (ATP). Interestingly, mammalian cell cytochrome C oxidase has uptake peaks in the NIR region. Mitochondria are the primary sites of light effects, production of ATP, modification of reactive oxygen species, and induction of transcription factors. These events, in turn, lead to increases in cell proliferation and migration, as well as increases in cytokine levels, growth factors, inflammatory mediators and tissue oxygenation. Changes in biochemical and cellular outcomes in animals and patients include benefits such as increased healing of chronic wounds, carpal tunnel syndrome, pain reduction in arthritis, neuropathy, as well as reduced damage after heart attacks, stroke and nerve injury [24]

\section{Laser light}

The effect of laser light at the cellular level (Figure 2) is based on the absorption of monochromatic visual radiation from by the components of the mitochondrial respiratory chain. The initial photoreceptor of red light is cytochrome $\mathrm{C}$ oxidase. Furthermore, absorption spectra obtained for cytochrome $\mathrm{C}$ oxidase and recorded in various oxidation states are similar to the spectra reflecting the biological responses to light [8]. Thus, laser light can stimulate biological processes in the mitochondria to produce energy, which is similar to what occurs within the mitochondria in the alveolar cells of the lung tissue.

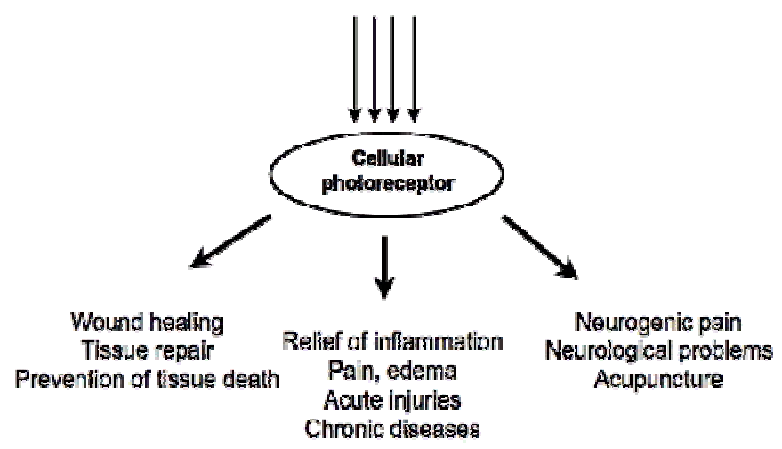

Figure 2: Therapeutic effect of laser light on tissues

Studies have accounted for how the absorption of photon produces laser energy [25]. Absorption of photons by molecules causes electron excitation, resulting in accelerated electron transfer. This transport increases ATP production, and also increases light-induced ATP synthesis through increased proton gradients.

\section{CONCLUSION}

The findings of this study demonstrate that prolonged administration of $\mathrm{AM}$ in rats induces lung fibrosis. Thus, withdrawal of $\mathrm{AM}$ and treatment by LC and/or exposure to laser can potentially produce significant amelioration of AM-induced fibrosis. 


\section{DECLARATIONS}

\section{Acknowledgement}

The authors are thankful to Ain Shams University, Cairo, Egypt for providing support for this work.

\section{Conflict of Interest}

No conflict of interest associated with this work.

\section{Contribution of Authors}

The authors declare that this work was done by the authors named in this article and all liabilities pertaining to claims relating to the content of this article will be borne by them.

\section{Open Access}

This is an Open Access article that uses a funding model which does not charge readers or their institutions for access and distributed under the terms of the Creative Commons Attribution License (http://creativecommons.org/licenses/by/ 4.0) and the Budapest Open Access Initiative (http://www.budapestopenaccessinitiative.org/rea d), which permit unrestricted use, distribution, and reproduction in any medium, provided the original work is properly credited.

\section{REFERENCES}

1. Mayo Clinic Staff. Definition of pulmonary fibrosis. Mayo Foundation for Medical Education and Research 2014; 1-22.

2. Camm AJ, Al-Saady NM, Opie LH, Gersh BJ. Drugs for the heart. Philadelph Saund 2001; 5: 221-251, 162163.

3. Hartmann A, Speit G. Genotoxic effects of chemicals in the single cell gel (SCG) test with human blood cells in relation to the induction of sister chromatid exchanges. Mutat Res 1995; 346: 49-95.

4. Schwaiblmair M, Berghaus $T$, Haeckel $T$, Wagner $T$, von Scheidt W. Amiodarone-induced pulmonary toxicity: an under-recognized and severe adverse effect? Clin Res Cardiol 2010; 99(11): 693-700.

5. Nacca N, Bhamidipati CM, Yuhico LS, Pinnamaneni S, Szombathy T. Severe amiodarone induced pulmonary toxicity. J Thorac Dis 2012; 4(6): 667-670.

6. Lango $R$, Smolenski RT, Rogowski J, Siebert J, Wujtewicz M, Slominska EM, Lysiak-Szydlowska W, Yacoub $\mathrm{MH}$. Propionyl-L-carnitine improves hemodynamics and metabolic markers of cardiac perfusion during coronary surgery in diabetic patients. Cardiovasc Drugs Ther 2005; 19(4): 267-275.
7. Javad T, Hashmi MD, Ying-Ying Huang MD, Bushra Z, Osmani MD, Sulbha $K S$, Margaret $A$, Naeser $L$, Hamblin PM. Role of Low-Level Laser Therapy in Neurorehabilitation. US Nati Lib of Medi 2010; 2(12): 292-305.

8. Karu T. Laser biostimulation: a photobiological phenomenon. J Photochem. Photobiol. 1989; 3: 638640.

9. Gado AM, Aldahmash BA. Protective Effect of L-Carnitine against Amiodarone-Induced Lung Toxicity in Rats. Internet. Toxicol. 2013; 10: 11-34.

10. Zickri MB, Aboul-Fadl SG, Metwally HG. Comparative Study between Intravenous and Intraperitoneal Stem Cell Therapy in Amiodarone Induced Lung Injury in Rat. Int J Stem Cells 2014; 7 (1): 103-114.

11. U.S. National Research Council of the National Academics, Guide for the Care and Use of Laboratory Animals [8th edition]. Available from: [National Academic Press Website] https://www.nap.edu/ $\mathrm{read} / 12910$

12. de Souza A, da Fonseca AL, Mencalha VM, Araújo de Campos SC, Ferreira Machado AA, de Freitas P. DNA repair gene expression in biological tissues exposed to low-intensity infrared laser. Lasers Med. Sci 2013; 28: 1077-1084.

13. Tello R, Crewson PE. Hypothesis testing II: mean. Radiol 2003; 227: 1-4.

14. Mali $P$, Salzman $M H$, Vidaillet $H J$, Rezkalla $S H$. Amiodarone therapy for cardiac arrhythmias: Is it associated with the development of cancers? World $\mathrm{J}$ Cardiovasc Dis 2014; 4: 109-118.

15. Al-Shammari B, Khalifa M, Bakheet $S$ A, Yasser M. A Mechanistic Study on the Amiodarone-Induced Pulmonary. Toxicity Oxid Med and Cell Long 2016; 2: 110.

16. Chakraborty A, Mondal C, Sinha S, Mandal J, Chandra AK. Amiodarone induced oxidative stress in stress vulnerable organs of adult male rats. Asian J Pharm Clin Res. 2014; 7: 177-183.

17. Kinnula VL, Fattman CL, Tan RJ, Oury TD. Oxidative stress in pulmonary fibrosis: a possible role forredox modulatory therapy. Am J RespiCrit Care Med 2005;172: 417-422.

18. Punithavathi D, Venkatesan N, Babu M. Protective effects of curcumin against amiodarone-induced pulmonary fibrosis in rats. Br J Pharmacol 2003; 139: 1342-1350.

19. Hassanein EHM, ABO-Youssef AM, Messiha BAS, Hemeida RAM. Protective Effects of Montelukast and Lcarnitine on Cyclophosphamide-Induced Lung Injury. Pharm \& biosci 2015; 3 (1): 30-36.

20. Atalay-Guzel N, Erikoglu OG, Bircan FS, Coskun CS. Effects of acute L-carnitine supplementation on nitric oxide production and oxidative stress after exhaustive exercise in young soccer players. J. Sports Med. Phys. Fitness. 2014; 149-159.

21. Lee BJ, Lin JS, Lin YC, Lin PT. Effects of L-carnitine supplementation on oxidative stress and antioxidant 
enzymes activities in patients with coronary artery disease: a randomized, placebo-controlled trial. Nutr $J$ 2014; 13(1): 79- 158.

22. de Lima FM, Albertini R, Dantas $Y$, et al. Low-level laser therapy restores the oxidative stress balance in acute lung injury induced by gut ischemia and reperfusion. Photochem Photobiol 2013; 89(1): 179-188.
23. Merino JL, Perez-de Isla L. treatment with amiodarone: how to avoid complications. J Cardiol Pract 2011; (10): $2-20$.

24. Michael RH, Ronald WW, Juanita A. Mechanisms for Low-Light Therapy J. Published in SPIE Proceedings 2006; 6-140.

25. Passarella $S$, He-Ne. laser irradiation of isolated mitochondria. J Photochem Photobiol B 1989; 3: 642643. 